\title{
Suspended Matter and its Composition from the Data on Light Scattering at the Large-Scale Polygon in the Northern Part of the Tropical Atlantic Ocean
}

\author{
V. I. Man'kovsky*, D. V. Grinchenko \\ Marine Hydrophysical Institute, Russian Academy of Sciences, Sevastopol, Russian Federation \\ *e-mail: emankovskaya@mail.ru
}

\begin{abstract}
The results of defining the mass and numerical concentration both of total suspended matter and its organic and mineral fractions at the large-scale polygon in the northern part of the tropical Atlantic Ocean in summer, 1986 are represented. The samples were taken from the $3 \mathrm{~m}$ depth. To determine concentration and composition of the suspended matter, the method of converting the light scattering functions measured at the polygon was used. Distribution of concentrations of the suspended matter different fractions was compared with the water dynamics. The maximum values of the suspended matter concentration are observed in the regions of the current divergence and their cyclonic vorticity. The source of the mineral suspended matter in the ocean regions remote from the continents are the aerosols as well as the phytoplankton species containing mineral particles on their shells, namely the silicon oxides (diatoms) and the carbonates (coccolithophorides). The data of biological investigations testify that both the mass development of diatoms at the polygon and maximum concentrations of the mineral suspended matter are observed in the equatorial region and in the area of the Countercurrent divergence. The mineral suspension relative content in the total mass concentration varies within 4 $19 \%$. As for quantity, the overwhelming majority of the total suspended matter (94-96\%) consists of mineral particles. The average particle sizes are determined for the organic and mineral suspensions. Their distribution at the polygon correlates with the distribution of the mass concentration: in the regions with the low suspended matter concentration, the mean radius of the organic particles is high, whereas that of the mineral ones is small. Having been compared, the mean sizes of the organic particles calculated using the light scattering function and those of the phytoplankton cells defined due to a microscope demonstrate their nearly complete similarity.
\end{abstract}

Keywords: light scattering function, organic and mineral suspended matter, sizes and number of particles.

Acknowledgements. The present study was carried out in FSBSI MHI within the framework of the State Order No. 0827-2014-0010.

For citation: Man'kovsky, V.I. and Grinchenko, D.V., 2018. Suspended Matter and its Composition from the Data on Light Scattering at the Large-Scale Polygon in the Northern Part of the Tropical Atlantic Ocean. Physical Oceanography, [e-journal] 25(3), pp. 235-246. doi: 10.22449/1573-160X2018-3-235-246

DOI: 10.22449/1573-160X-2018-3-235-246

(c) 2018, V. I. Man’kovsky, D. V. Grinchenko

(C) 2018, Physical Oceanography

\section{Introduction}

There are suspended in water particles of various origin in all natural basins. They are generally called "suspension". Suspension plays an important role in a great variety of biological, physical and geochemical processes taking place in the aquatic environment. Consequently, the analysis of the suspended matter concentration and composition in natural waters is a relevant objective.

A number of works have been devoted to the research of the suspended matter content and sources of its intake to the Atlantic Ocean waters. These were carried out based on observations along the meridional sections across the ocean in the PHYSICAL OCEANOGRAPHY VOL. 25 ISS. 32018 
$\mathrm{R} / \mathrm{V}$ cruises and according to the satellite data [1, 2]. Data on the oceanic suspension in various climatic zones of the Atlantic are presented in the aforementioned works.

The present study gives the results of defining the mass and numerical concentration both of total suspended matter and its organic and mineral fractions at the large-scale polygon in the northern part of the tropical Atlantic Ocean according to the light scattering data.

The suspended matter affects the light scattering nature in water. There are inversion methods for the light scattering function, which make it possible to determine the numerical and mass concentrations of organic and mineral particles and their total concentration according to the scattering indices $\sigma(\theta)$ [3]. Such methods were used in $[4,5]$ to determine the suspended matter concentration and composition in the Black Sea and in Lake Baikal. In this paper, such method was used to determine the suspended matter concentration and composition in the tropical Atlantic Ocean.

\section{Study area}

The research was carried out in the $47^{\text {th }}$ cruise of R/V Mikhail Lomonosov (July-September 1986) on a large-scale tropical polygon with the boundaries of $1^{\circ} \mathrm{S}-12^{\circ} \mathrm{N}, 16-32.5^{\circ} \mathrm{W}$. The meridional sections were located in $1.5^{\circ}$ along the longitude; the stations on sections were performed with an interval of $0.5^{\circ}$ in latitude.

\section{Apparatus}

Light scattering functions were measured by the nephelometer [6] in water samples taken from a depth of $3 \mathrm{~m}$. Technical characteristics of nephelometer are given in Tab. 1.

Table 1

Technical Characteristics of Nephelometer

\begin{tabular}{lc}
\hline \multicolumn{1}{c}{ Characteristic } & Value \\
\hline Angles of measurements $\sigma(\theta)$, degree & $2 ; 7.5 \ldots(5) \ldots 162.5$ \\
Spectral range of measurements, nm & $520( \pm 40)$ \\
Measurement error $\sigma(\theta), \%$ & 10 \\
Maximum depth of submergence, $m$ & 150 \\
\hline
\end{tabular}

The minimum angle that the light scattering index is determined at in the nephelometer is $2^{\circ}$. The light scattering indices for angles $\theta<2^{\circ}$, necessary for the suspended matter calculation, were obtained by extrapolating the measured function to this region by the formula $\lg \sigma(\theta)=A+B \theta+C \theta^{2}$. To obtain the $\mathrm{A}, \mathrm{B}, \mathrm{C}$ coefficients, the measured scattering indices $\sigma(\theta)$ at angles $\theta=2 ; 7,5 ; 12,5^{\circ}$ were used.

\section{Suspended matter calculation formulas}

To calculate the characteristics of a suspension according to the scattering functions, the formulas from [7, 8] were applied. 
In [7] formulas for the calculation of the light scattering parameters $(\lambda=$ $=546 \mathrm{~nm}$ ) of the numerical and mass concentration of particles for three fractions with particle radii: $r=0.2 \div 0.5 \mu \mathrm{m}, r=0.5 \div 1.0 \mu \mathrm{m}, r>1.0 \mu \mathrm{m}$ are given. The particles having radii $r=0.2 \div 0.5 \mu \mathrm{m}, r=0.5 \div 1.0 \mu \mathrm{m}$ compose the mineral fraction of the suspended matter, the ones with radii $r>1.0 \mu \mathrm{m}$ - the organic fraction. When calculating the mass concentration, the density of mineral particles is assumed equal to $2 \mathrm{~g} \cdot \mathrm{cm}^{-3}$, the density of the organic ones $-1 \mathrm{~g} \cdot \mathrm{cm}^{-3}$.

To calculate the concentration of the particles with radii $r>1.0 \mu \mathrm{m}$ the scattering index $\sigma(\theta)$ at the angle $\theta=1^{\circ}$ is used, for the particles $r=0.2 \div 0.5 \mu \mathrm{m}$ and $r=0.5 \div 1.0 \mu \mathrm{m}-$ at angles $\theta=45^{\circ}$ and $\theta=6^{\circ}$. Tab.2 shows the coefficients for calculating the number of particles $N$ and their mass concentration $C$ according to the formula $N(C)=m \cdot \sigma(\theta)+n$.

In a number of samples, the suspended matter concentration of at the polygon was determined by the gravimetric method. A comparison of the total suspended matter concentration calculated from the formulas of [7] and a certain gravimetric method was carried out. The coupling equation has the following form

$$
\tilde{N}_{\text {calc }}=0,97 \cdot \tilde{N}_{\text {grav }}+0.009 \text {. }
$$

The correlation coefficient is $R=0.875 \pm 0.05$. The root-mean-square regression error $S\left(C_{\text {calc }}\right)=0.07 \mathrm{mg} / \mathrm{l}$. In the range of concentrations $0.35-0.80 \mathrm{mg} / \mathrm{l}$ the difference between $C_{\text {calc }}$ and $C_{\text {grav }}$ according to the formula (1) doesn't exceed $0.015 \mathrm{mg} / \mathrm{l}$. Due to the insignificant difference between $C_{\text {calc }}$ and $C_{\text {grav }}$, an adjustment to $C_{\text {calc }}$ was not introduced.

Table 2

Values of the Regression Coefficients $\boldsymbol{m}, \boldsymbol{n}$ and the Root-Mean-Square Relative Errors $\delta$ in Determining the Suspended Matter Parameters

\begin{tabular}{c|c|c|c|c|c|r|c}
\hline Radius of & Diffusion & \multicolumn{2}{c|}{ Number of particles $N, \mathrm{mln} / \mathrm{l}$} & \multicolumn{3}{|c|}{ Mass concentration $C, \mathrm{mg} / \mathrm{l}$} \\
\cline { 5 - 9 } $\begin{array}{c}\text { particles } r, \\
\text { mcm }\end{array}$ & angle $\theta$, & $m$ & $n$ & $\delta N$ & $m$ & $n$ & $\delta C$ \\
\hline $0.2-0.5$ & 45 & $3 \cdot 10^{4}$ & -1.0 & 0.29 & $8.9 \cdot 10^{3}$ & -3.0 & 0.16 \\
$0.5-1.0$ & 6 & 9.5 & 0.2 & 0.14 & 24.0 & 0.5 & 0.14 \\
$>1.0$ & 1 & 0.2 & 0.3 & 0.35 & 12.0 & 16.0 & 0.20 \\
\hline
\end{tabular}

In [8] to calculate the characteristics of the suspended matter $\xi$ the following generalized formula is given

$$
\xi=A\left[B-\lg \frac{\sigma\left(\theta_{1}\right)}{\sigma\left(\theta_{2}\right)}\right]^{P}+C \lg \left[\frac{\sigma\left(\theta_{1}\right)}{\sigma\left(\theta_{2}\right)}\right]+D .
$$

The scattering indices $(\lambda=546 \mathrm{~nm})$ at angles $\theta=0.5 ; 2 ; 15$; $90^{\circ}$ are given. According to the scattering indices $\sigma(0.5)$ and $\sigma(2)$ the mean radius of organic particles $r_{\text {org }}$ is determined, according to $\sigma(15)$ and $\sigma(90)$ - the dispersion parameter $v$ of mineral particles (Young parameter). In accordance to $v$ the mean 
radius of the mineral particles $r_{\text {miner }}=\frac{(v-1)}{(v-2)} \cdot \frac{\left(r_{\max }^{2-v}-r_{\min }^{2-v}\right)}{\left(r_{\max }^{1-v}-r_{\min }^{1-v}\right)}$, is calculated, where: $r_{\min }=0.02 \mu \mathrm{m} ; r_{\max }=2.0 \mu \mathrm{m}$. The coefficients $A, B, C, D, P$ in the formula (2) are determined in [8] according to the specific table.

\section{Results and discussion}

Mass concentration of suspended matter. The range of variation in the mass concentration of organic suspended matter at the polygon was $0.145-0.700 \mathrm{mg} / \mathrm{l}$, of the mineral one $-0.010-0.100 \mathrm{mg} / \mathrm{l}$, of the total one $-0.155-0.800 \mathrm{mg} / \mathrm{l}$ (Fig. $1-3$ ).

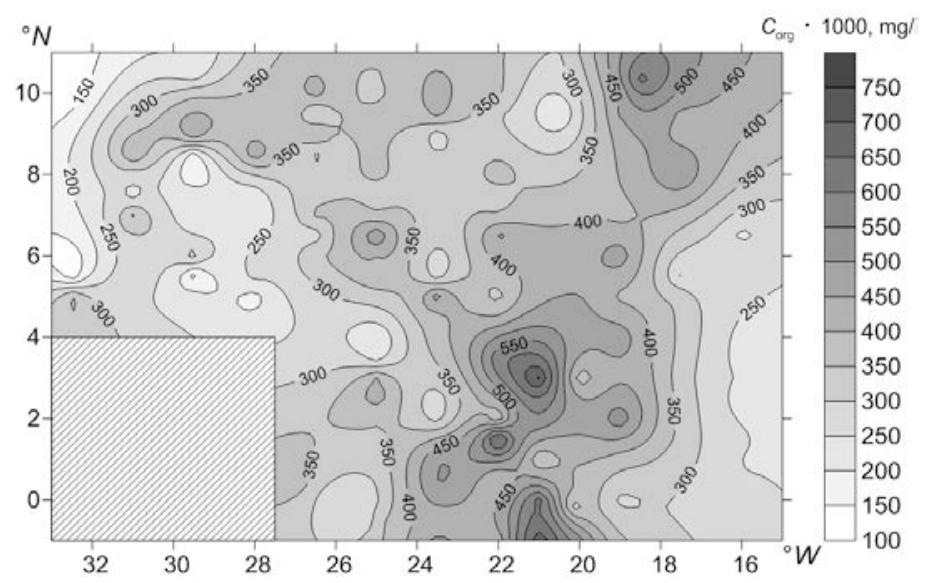

Fig. 1. Distribution of the organic suspended matter concentration $C_{\text {org }} \cdot \times 10^{3}, \mathrm{mg}^{\cdot} \mathrm{l}^{-1}$

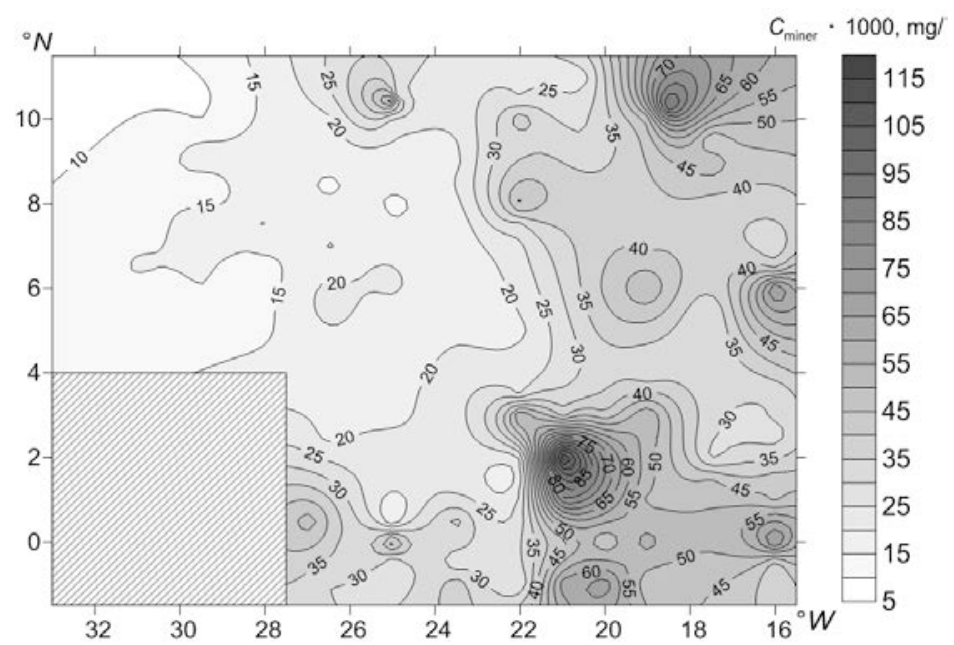

Fig. 2. Distribution of the mineral suspended matter concentration $C_{\text {miner }} \times 10^{3}, \mathrm{mg} \cdot \mathrm{l}^{-1}$

[9]. Below the suspended matter distribution at the polygon due to the water dynamics is considered. In the surface oceanic waters, the main contribution to the variability of the suspended matter concentration is made by organic particles - 
phytoplankton and its decomposition products (detritus) [9]. The phytoplankton concentration depends on the vertical dynamics of the waters - their rise and lowering. With the rise of water, biogenic substances are taken from the deep layers to the surface (euphotic zone), which contributes to the development of phytoplankton and leads to an increase in the suspended matter concentration. When the waters low down, the content of nutrients in the euphotic zone becomes low and phytoplankton development becomes more difficult, the concentration of suspended matter decreases. Thus, the variability of the organic suspended matter concentration is closely related to the vertical dynamics of the waters in the studied ocean area.

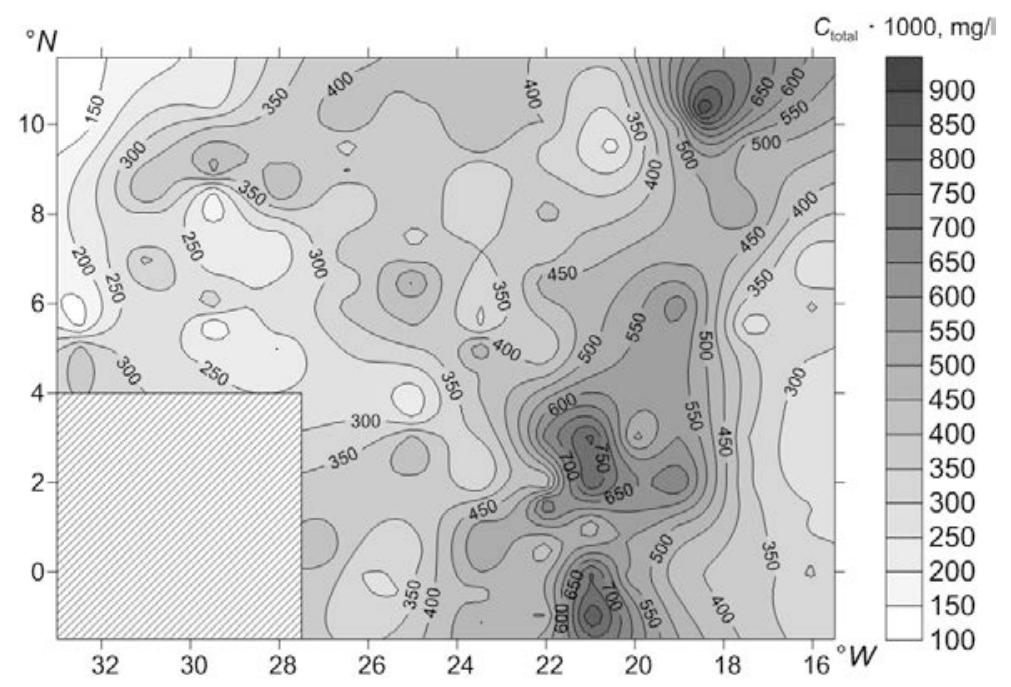

Fig. 3. Distribution of the total suspended matter concentration $C_{\text {total }} \times 10^{3}, \mathrm{mg}^{-1} \mathrm{l}^{-1}$

Variability of the mineral suspended matter content in ocean waters is also associated with the water dynamics, but in a different way - through phytoplankton. Some species of phytoplankton (diatoms, coccolithophorides) contain mineral substances. With the death of these algae, mineral particles enter the water in the form of structural elements of cells composed of the silicon oxides (diatoms) and the carbonates (coccolithophorides) [9].

The silicon oxides in diatoms are contained in the shell that covers the cell. Dimensions of diatom cells are tens of microns [10]. Coccolithophoride has calcareous discs on the outer shell - coccoliths - in the amount of 15 pcs. Their diameter is about $1 \mu \mathrm{m}$, a thickness of $0.25 \mu \mathrm{m}$. Cells of the species Emiliania huxsleyi can dump coccoliths, and then the number of coccoliths in the water in relation to the number of cells can be much larger, according to the data of [11], up to 400 , and their concentration in water is about $10^{10}-10^{11} \mathrm{pc} \cdot \mathrm{m}^{-3}$.

The process of rising and lowering the waters in the ocean indicates the nature of the currents. In the cyclonic movement and in the divergence regions of the currents, there is a rise of the waters, in the anticyclonic movement and in the areas of convergence of currents - the water lowering takes place. 
Fig. 4 shows a map of surface currents at the polygon, compiled using the dynamic method [13]. In the near-equatorial region, currents are not shown, since here the dynamic method does not work because of the very small value of the Coriolis force and its conversion to the zero at the equator.

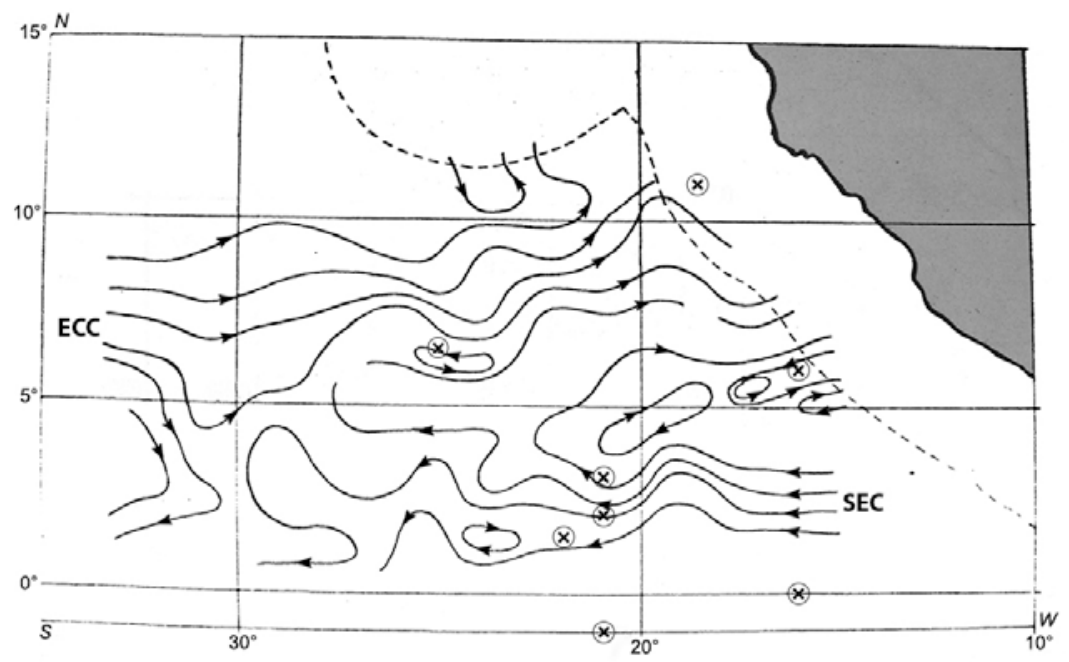

Fig. 4. Currents on the surface based on the calculations by the dynamic method: CC is the Countercurrent and SC is the Southern Countercurrent. Crosses show the points where high concentration of the suspended matter is observed

In the northern part, the Equatorial Counter Current (CC) passed through the polygon, which $20^{\circ} \mathrm{W}$ eastward was divided into several branches, leaving in the northern and southern directions. In the southeastern part of the polygon, the South Equatorial Current (SC) passed, in which $20^{\circ} \mathrm{W}$ westward a divergence of its jets was observed.

On the map of currents, crosses show the position of points with a high organic and mineral suspended matter concentration. The concentration of each suspended matter can be divided into three levels: 1) low; 2) medium; 3) high. For organic suspension, the range of values is $0.15-0.25$; $0.25-0.45$; more than $0.45 \mathrm{mg} / \mathrm{l}$, respectively, for the mineral suspension - 0.005-0.025; $0.025-0.045$; more than $0.045 \mathrm{mg} / \mathrm{l}$. Tab. 3 shows the coordinates of points with a high suspended matter concentration.

A comparison with the map of currents shows that the points with a high suspended matter concentration are in the places of water rise caused by the divergence of the currents and their cyclonic movement.

In the near-equatorial region, places with a high suspended matter concentration, points 7 and 8, are also observed. High concentrations of suspended matter in this region are associated with the rise of water in the Equatorial Under Current (subsurface current $\approx 20-200 \mathrm{~m}$ of the eastern direction along the equator in the strip of $\left.\approx 1.5^{\circ} \mathrm{N}-1.5^{\circ} \mathrm{S}[12]\right)$.

The following peculiarity in the distribution of high concentrations of suspended matter should be noted: at some points, a high concentration of only one of the fractions was observed: at points 2, 4, 6- of the organic suspended matter, at 
points 3, 5, 7 - of the mineral one. For the other fraction at these points, the suspended matter concentration was at an average level. This can be explained by a different contribution to the biomass of different phytoplankton species containing and non-containing mineral components.

Table 3

The points where high concentrations of the organic and mineral suspended matter are observed and the dynamic reasons of water elevation there

\begin{tabular}{|c|c|c|c|c|}
\hline $\begin{array}{c}\text { Point } \\
\text { number }\end{array}$ & Latitude & Longitude & $\begin{array}{c}\text { Type of } \\
\text { suspension }\end{array}$ & Reason of water elevation \\
\hline 1 & $10.5^{\circ} \mathrm{N}$ & $18.5^{\circ} \mathrm{W}$ & $\begin{array}{l}\text { Organic } \\
\text { Mineral }\end{array}$ & Countercurrent divergence \\
\hline 2 & $6.5^{\circ} \mathrm{N}$ & $25.0^{\circ} \mathrm{W}$ & $\begin{array}{l}\text { Organic } \\
\text { Mineral }\end{array}$ & Cyclone \\
\hline 3 & $6.0^{\circ} \mathrm{N}$ & $16.0^{\circ} \mathrm{W}$ & $\begin{array}{l}\text { Organic } \\
\text { Mineral }\end{array}$ & Cyclone \\
\hline 4 & $3.0^{\circ} \mathrm{N}$ & $21.0^{\circ} \mathrm{W}$ & $\begin{array}{l}\text { Organic } \\
\text { Mineral }\end{array}$ & $\begin{array}{l}\text { Southern Countercurrent } \\
\text { divergence }\end{array}$ \\
\hline 5 & $2.0^{\circ} \mathrm{N}$ & $21.0^{\circ} \mathrm{W}$ & $\begin{array}{l}\text { Organic } \\
\text { Mineral }\end{array}$ & $\begin{array}{c}\text { Southern Countercurrent } \\
\text { divergence }\end{array}$ \\
\hline 6 & $1.5^{\circ} \mathrm{N}$ & $22.0^{\circ} \mathrm{W}$ & $\begin{array}{l}\text { Organic } \\
\text { Mineral }\end{array}$ & $\begin{array}{c}\text { Southern Countercurrent } \\
\text { divergence }\end{array}$ \\
\hline 7 & 0 & $16.0^{\circ} \mathrm{W}$ & $\begin{array}{l}\text { Organic } \\
\text { Mineral }\end{array}$ & Equatorial divergence \\
\hline 8 & $1.0^{\circ} \mathrm{S}$ & $21.0^{\circ} \mathrm{W}$ & $\begin{array}{l}\text { Organic } \\
\text { Mineral } \\
\end{array}$ & Equatorial divergence \\
\hline
\end{tabular}

According to biological observations carried out on the $47^{\text {th }}$ cruise, the development of mineral-containing phytoplankton species (diatoms, coccolithophorides) was observed in different parts of the polygon. It was noted that diatoms developed in a significant amount in the equatorial zone, especially in its eastern part, and in the northeastern part of the polygon in the CC divergence region. Comparing the distribution of high concentrations of mineral supended matter (Fig. 2) with biological data, it is possible to explain $C_{\text {miner }}$ high concentrations in the $\mathrm{CC}$ divergence region (point 1 ) and in the equatorial region (points 7,8 ) by the development of diatoms.

By the suspended matter concentration the polygon is divided into two parts, approximately along $23^{\circ} \mathrm{W}$. In the eastern part of the polygon the suspended matter concentration is higher, especially for the mineral suspended matter. This is explained by the features of water dynamics in different parts of the polygon. In the eastern part two large water rise areas in the places of CC and SC divergence were observed, as well as intensive water rise at the equator near $20-21^{\circ} \mathrm{W}$. In the western part of the polygon between the CC and SC, a large area with anticyclonic movement of waters, at which their lowering takes place, was 
formed. Moreover, in the CC in the area from $29^{\circ}$ to $21^{\circ} \mathrm{W}$, the convergence of its fluxes accompanied by the lowering of waters was recorded.

Fig. 5 shows the distribution of mineral fraction relative content in the suspended matter at the polygon. $C_{\text {miner }} / C_{\text {total }}$ values are divided into three levels: low - from 0.03 to 0.06 ; medium - from 0.06 to 0.10 ; high - more than 0.10 . High $C_{\text {miner }} / C_{\text {total }}$ values were observed at the sites with high mineral suspended matter concentration (Fig. 2). Exception is the area of CC divergence - there was recorded medium $C_{\text {miner }} / C_{\text {total }}$ level.

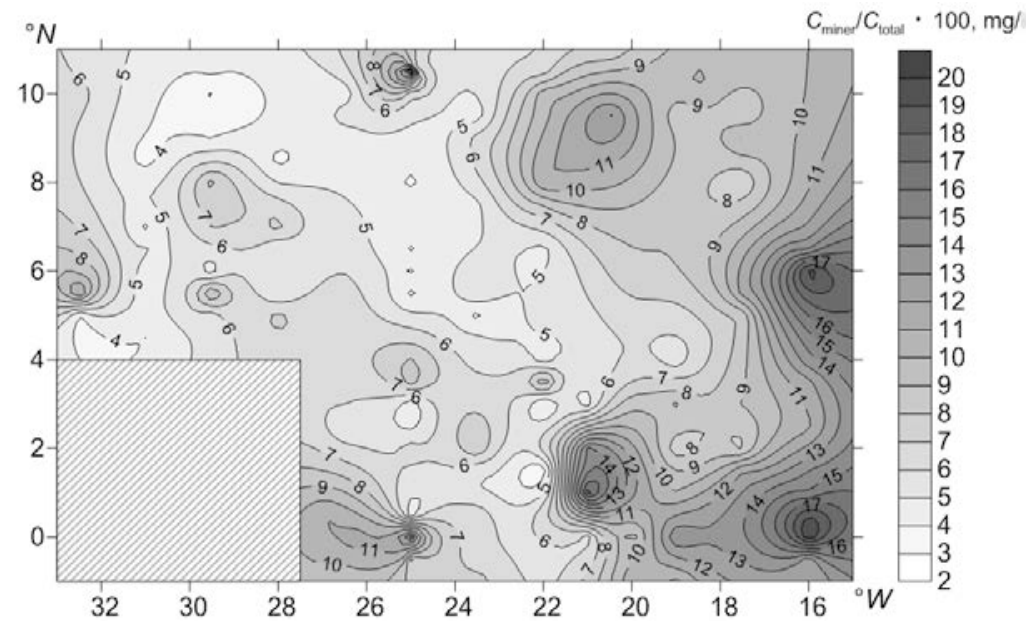

Fig. 5. Distribution of relative concentration of the mineral suspended matter $C_{\text {miner }} / C_{\text {total }} \times 10^{2}$

Comparison of $C_{\text {miner }} / C_{\text {total }}$ distribution with the one of organic suspended matter concentration (Fig. 3 ) indicates $C_{\text {miner }} / C_{\text {total }}$ value increase in the areas with low $C_{\text {org }}$ concentration.

Numerical concentration of suspended matter. The range of change of organic suspended matter numerical concentration at the polygon varied within 2.0$12.0 \mathrm{mln} / \mathrm{l}$, mineral $-48-250 \mathrm{mln} / \mathrm{l}$, total $-50-262 \mathrm{mln} / \mathrm{l} ; C_{\text {miner }} / C_{\text {total }}$ ratio -0.94 0.96. The distribution of numerical concentration of organic and mineral particles is shown in Fig. 6. According to quantity, the vast majority of suspended matter fell on mineral particles $-0.94-0.96 \%$.

The character of numerical distribution of organic and mineral particles (Fig. 6) at the polygon is similar to the one of corresponding distributions of organic and mineral suspended matter mass concentration (see Fig. 1, 2). 

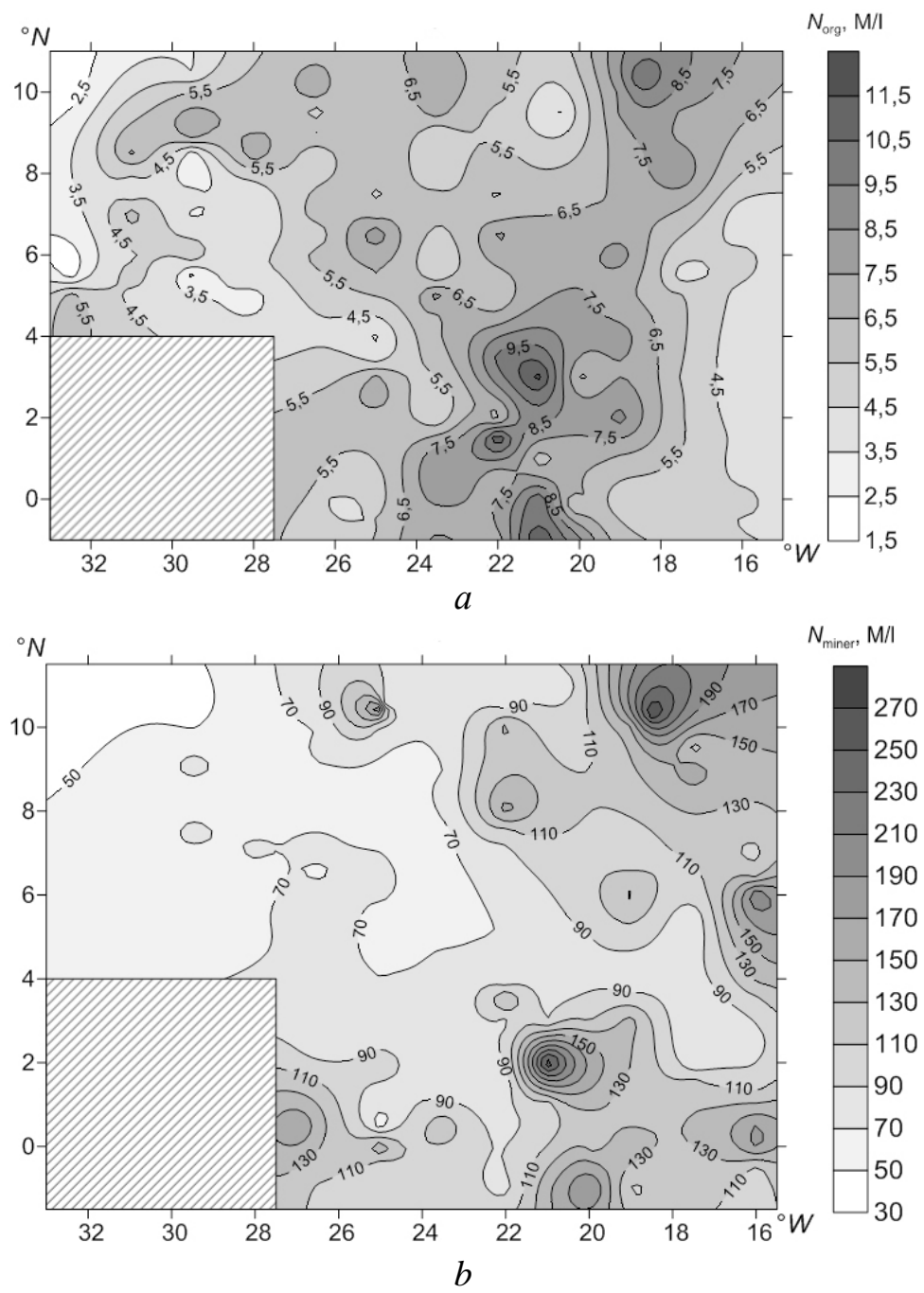

Fig. 6. Distribution of the quantity of the organic particles $N_{\mathrm{org}}, \mathrm{mln} \cdot \mathrm{l}^{-1}(a)$ and that of the mineral particles $N_{\text {miner, }} \operatorname{mln} \cdot l^{-1}(b)$

The sizes of suspended matter particles. The variation range of medium radii of particles at the polygon was: organic suspended matter_- 3.4-4.6 $\mu \mathrm{m}$, mineral one $-0.026-0.054 \mu \mathrm{m}$. Their distribution at the polygon is shown in Fig. 7.

Comparison with Fig. 1 indicates that for organic suspended matter in general the increase of particle sizes with the suspended matter concentration decrease is observed. However, in some sites the anomalies take place, for instance, in the area with $10^{\circ} \mathrm{N}, 20^{\circ} \mathrm{W}$ coordinates. This means that the relation of organic particle sizes with the suspended matter concentration is ambiguous.

In the water samples from the surface biologists determined the sizes of phytoplankton cells and their mean radius by the microscope. In the same samples the radius of biological particles was calculated according to data on light scattering. Mean values of organic particle radii (59 samples) were: $r_{\text {scat }}=$ 
$=4.17 \mu \mathrm{m}, r_{\text {biol }}=4.39 \mu \mathrm{m}$. The difference between mean calculated and measured radii of particles is $5 \%$. This means that the formulas for calculation of organic particle sizes according to data on light scattering give the same results as according to instrumental measurements.

Distribution of mineral particle sizes at the polygon (Fig. 7, b) shows that in general their sizes in the eastern part of the polygon are greater than the ones in the western. Especially large values of $r_{\text {miner }}$ are observed in the waters i9n the southeastern part of the polygon: at $16^{\circ} \mathrm{W}, 0^{\circ} \mathrm{N}$ and $17.5^{\circ} \mathrm{W}$ from 1.5 to $5.5^{\circ} \mathrm{N}$. Thus, outside this region mean radius of mineral suspended matter particles at the polygon is $0.026-0.029 \mu \mathrm{m}$ and in the mentioned area at $17.5^{\circ} \mathrm{W} r_{\text {miner }}$ reaches $0.054 \mu \mathrm{m}$. Considering the possible causes of extremely high $r_{\text {miner }}$ values at $17.5^{\circ} \mathrm{W}$ due to water dynamics, we should notice that a convergence of currents is observed in this region (Fig. 4). However, there are no versions to explain how the size of mineral particles can be related with this process.
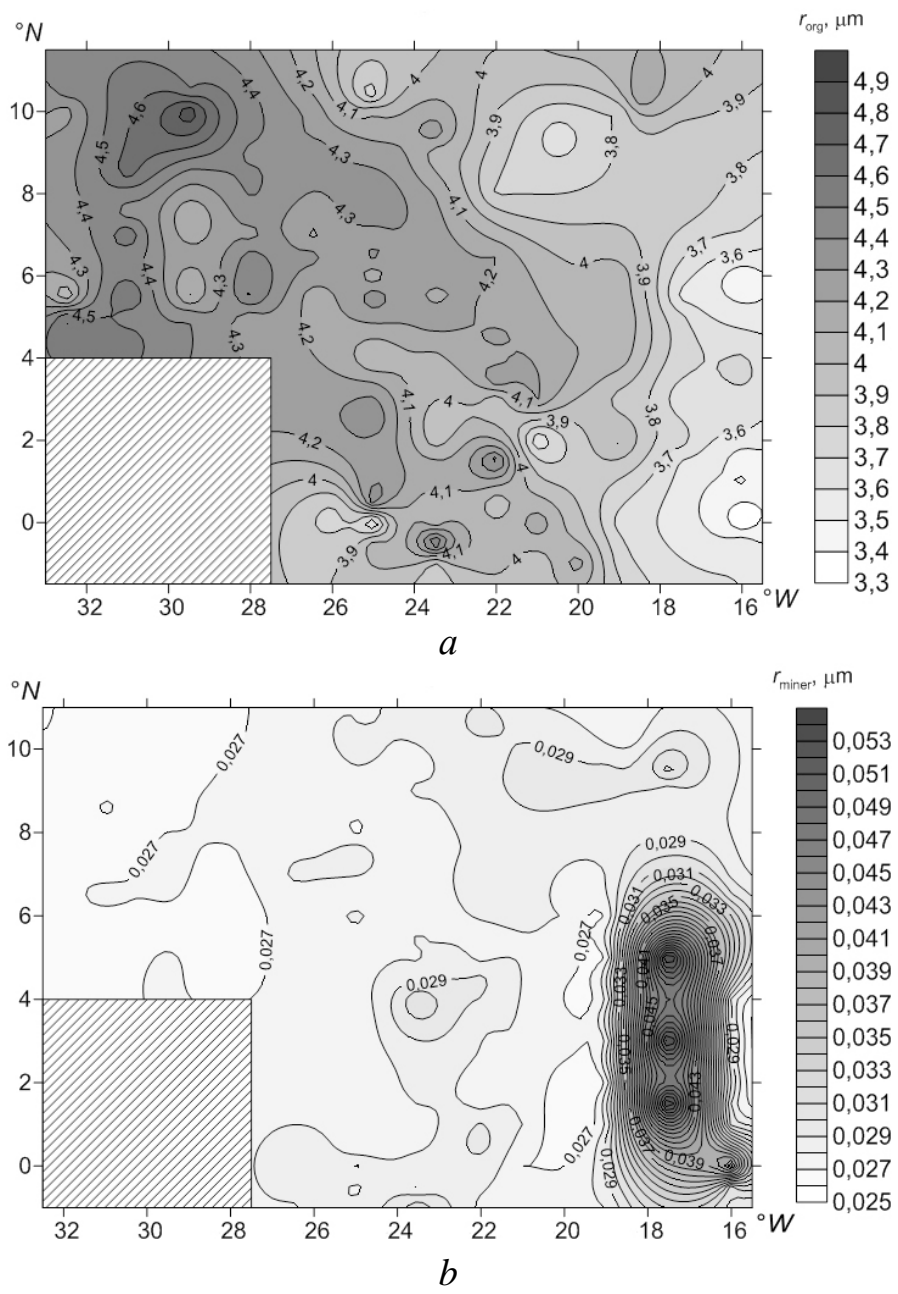

Fig. 7. Distribution of the mean radius of the organic particles $r_{\text {org }}$, mcm $(a)$ and that of the mineral particles $r_{\text {miner, }}$ mcm $(b)$ 


\section{Conclusion}

The mass and numerical concentration of total suspended matter and its organic and mineral fractions, as well as the mean sizes of organic and mineral particles, are determined from the measurements of light scattering functions in surface waters ( $3 \mathrm{~m}$ depth) at a large-scale polygon in the northern part of the of the Atlantic Ocean tropical zone.

A relationship of the distribution of suspended matter characteristics at the polygon with water dynamics, manifested in an increase of suspended matter concentration in the regions of divergence and cyclonic circulation of currents which water rises at, is shown.

In the suspended matter mass concentration the relative content of mineral fraction at the polygon was 4-19\%, in numerical concentration - 94-96\%.

The comparison of mean particle sizes calculated according to light scattering parameters with mean sizes of phytoplankton cells determined by means of a microscope indicated their almost similar values.

At the polygon areas with low suspended matter concentration the mean sizes of organic particles increased and the ones of mineral particles decreased. In the southeastern part of the polygon an exception from the mentioned regularity was observed: at low suspended matter concentration mean radius of particles was significantly higher than as a whole throughout the polygon.

\section{REFERENCES}

1. Klyuvitkin, A.A., Zernova, V.V. and Kravchishina, M.D., 2008. Raspredelenie Fitoplanktona i Vzvesi v Atlanticheskom Okeane v Oktyabre - Noyabre 2002 g. [Distribution of Phytoplankton and Suspended Matter in the Atlantic Ocean in October - November, 2002]. In: M.V. Flint ed., 2008. Kompleksnye Issledovaniya Mirovogo Okeana: Proekt «Meridian». Ch. 1, Atlanticheskiy Okean [Complex Research of the World Ocean: "Meridian" Project. Pt. 1, the Atlantic Ocean]. Moscow: Nauka, pp. 270-294 (in Russian).

2. Burenkov, V.I., Klyuvitkin, A.A. and Sheberstov, S.V., 2007. Suspended Matter Concentration in Surface Layers of the Atlantic Ocean Derived from Data of Ocean Color Scanner MODIS. In: IAP, 2007. Proceedings of IV International Conference "Current problems in Optics of Natural Waters” (ONW'2007). Nizhny Novgorod, September 11-15, 2007. Nizhny Novgorod: Institute of Applied Physics, pp. 154-156.

3. Shifrin, K.S., 1988. Physical Optics of Ocean Water. Chapter 6, Inverse problems. New York: American Institute of Physics, pp. 211-271.

4. Man'kovskii, V.I. and Solov'ev, M.V., 2005. Indicatrices of Scattering of Light and the Composition of Suspension in the Black Sea. Physical Oceanography, [e-journal] 15(1), pp. 55-70. https://doi.org/10.1007/s11110-005-0030-5

5. Man'kovsky, V.I., 2011. The Structure of Suspended Matter in Lake Baikal According to the Data of Measurements of Light Scattering Functions. Physical Oceanography, [e-journal] 21(3), pp. 163-181. https://doi.org/10.1007/s11110-011-9113-7

6. Man'kovskiy, V.I., 1981. Morskoy Impul'snyy Nefelometr [Marine Pulse Turbidimeter]. In: B.N. Malinovskiy and V.T. Cherepin eds., 1981. Pribory dlya Nauchnykh Issledovaniy i Sistemy Avtomatizatsii v AN USSR [Tools for Scientific Research and Automation Systems in AS USSR]. Kiev: Naukova Dumka, pp. 87-89 (in Russian).

7. Kopelevich, O.V., Mashtakov, Yu.A. and Burenkov, V.I., 1975. Issledovanie Vertikal'noy Stratifikatsii Rasseivayushchikh Svoystv Morskoy Vody [Vertical Stratification of the Scattering Properties of Sea Water and Its Study, Using an Underwater Narrow-Angle Scatterance Meter]. In: L.M. Brekhovskikh and K.S. Shifrin eds., 1975. Gidrofizicheskie i Gidroopticheskie Issledovaniya v Indiyskom Okeane: Po Resultatam Issledovaniy v 10-om 
Reise NIS "Dmitriy Mendeleev" [Hydrophysical and Hydrooptical Research in the Indian Ocean: According to the Research Results in the 10th Cruise of R/V Dmitriy Mendeleyev. Moscow: Nauka, pp. 54-60 (in Russian).

8. Oshhepkov, S.L. and Sorokina, E.A., 1988. Approximate Procedure for Determination of Marine Suspension Dispersivity and Concentration from Measurements of Diffusion Indicatrix. Oceanology, 28(1), pp. 157-161 (in Russian).

9. Vityuk, D.M., 1983. Vzveshennoye Veshchestvo i Ego Biogennye Komponenty [Suspended Matter and Its Biogenic Components]. Kiev: Naukova Dumka, 210 p.

10. Raymont, J. E.G., 1980. Plankton and Productivity in the Oceans. Vol. 1, Phytoplankton. Oxford; New York: Pergamon Press, 660 p.

11 Balch, W.M., Holligan, P.M., Ackleson, S.G. and Voss, K.J., 1991. Biological and Optical Properties of Mesoscale Coccolithophore Blooms in the Gulf of Maine. Limnology and Oceanography, [e-journal] 36(4), pp. 629-643. https://doi.org/10.4319/lo.1991.36.4.0629

12. Khanaychenko, N.K., 1974. Sistema Ekvatorial'nykh Protivotecheniy v Okeane [The System of Equatorial Countercurrents in the Ocean]. Leningrad: Gidrometeoizdat, pp. 131-132 (in Russian).

About the authors:

Victor I. Man'kovsky - Senior Research Associate, Sea Biogeochemistry Department, FSBSI MHI (2, Kapitanskaya St., Sevastopol, 299011, Russian Federation), Ph.D. (Phys.-Math.), ORCID ID: 0000-0002-4272-2218, emankovskaya@mail.ru

Dmitriy V. Grinchenko - Senior Engineer-Researcher, Sea Biogeochemistry Department, FSBSI MHI (2, Kapitanskaya St., Sevastopol, 299011, Russian Federation), phizeg@gmail.com

Contribution of the co-authors:

Victor I. Man'kovsky - selection of formulas for calculation of suspended matter parameters, analysis of performed calculations, article writing

Dmitriy V. Grinchenko - analysis and processing of the obtained data, design of figures and tables, article editing

All the authors have read and approved the final manuscript.

The authors declare that they have no conflict of interest. 